\title{
Increasing self-efficacy through immersive simulations: Leading professional learning communities.
}

\author{
Kristen A. Gilbert \\ Department of Teaching and Leading \\ Augusta University \\ Robert H. Voelkel, Jr. \\ Department of Teacher Education and Administration \\ University of North Texas \\ Christie W. Johnson \\ Department of Leadership, Research, and School Improvement \\ University of West Georgia
}

\begin{abstract}
Research suggests effective immersive simulations that rely on augmented reality enhance teachers' self-efficacy and skills (Badiee \& Kauffman, 2015). However, there is a gap in the literature as studies have largely ignored their uses in educational leadership programs (Bradley \& Kendall, 2015). This study investigated the relationship between application of critical skills within an immersive simulation environment and 26 school or district leaders' perceptions of self-efficacy in leading a professional learning community (PLC). Two overarching themes materialized from participants: improved general confidence in leading a PLC, and a sense of refined or expanded skills in the context of new approaches to leading PLC. Further studies are needed on the use of immersive simulation as a pedagogical tool and to examine impact for educational leadership practitioners.
\end{abstract}

\section{Introduction}

While a strong body of evidence secures the theoretical framework surrounding the discipline of leadership education, global demands for school improvement and leader accountability offer a compelling argument for renewed scholarly interest and a deeper dive into innovative new practices and theory. For this reason, examination of how the academy views and delivers educational leadership is crucial to productive professional discourse and practitioners' well-being.

School leadership is second only to classroom instruction for successful schools (Leithwood, Louis, Anderson, \& Wahlstrom, 2004). For the past 15 years, however, public school leaders in the United States have faced unprecedented challenges in meeting increased state and federal demands to raise student achievement and close racial and ethnic achievement gaps. The new Every Student Succeeds Act (U.S. Department of Education, 2015) and other policy changes, intended to provide state and local authorities greater flexibility, also call for school leaders to reshape traditional thinking in making decisions that will improve classroom instruction and achievement measures. To meet such demands, those teaching courses in educational leadership programs, focused on creating $21^{\text {st }}$ century-ready leaders, must continually seek new pedagogies and redefine traditional tools used to support 
school leaders in building and developing skills that can increase efficacy for themselves and others.

Instructional strategies that center on collaborative and critical pedagogy are among the most effective for improving teacher and leader efficacy while increasing student learning outcomes. Such methods, however, require an innovative approach to school restructuring and improvement for the many U.S. and international districts that have implemented professional communities or professional learning communities (Halverson, 2007; Lee, Zhang, \& Yin, 2011; Bolam, McMahon, Stoll, Wallace, \& Thomas, 2005). Though convincing empirical evidence supports the effectiveness of professional learning community models, school leaders often struggle in bringing them to full potential (Huberman, 1993; Little, 1995). Scribner, Cockrell, Cockrell, and Valentine (1999) found it is typically stressful for schools to sustain professional learning communities due to disconnecting or conflicting interests that can exist between what professional learning communities represent (caring for all students, critical reflection, and collaboration) and bureaucratic requirements of accountability and control. Poorly constructed support systems also contribute to difficulties with implementation of professional learning communities for schools, as district and building level leaders often fail to provide professional development or operational structures to facilitate teacher acquisition of knowledge and skills that can ensure learning community success (LaRocco, 2007). Other barriers include those commonly imposed by traditional teaching methods rooted in relative classroom isolation (Elmore, 2004; LaRocco, 2007) and other isolationist teaching practices that further complicate differing perceptions on what constitutes best instructional delivery (Ashton \& Webb, 1986).

High levels of teacher efficacy, essential to the shared beliefs of teachers that they can carry out tasks successfully, significantly and positively influence students' learning (Bandura, 1997; Goddard \& Goddard, 2001; Goddard, Hoy, \& Hoy, 2000/2004; Hattie, 2009). Because efficacy can affect teacher attitudes toward their own collective work as well as that of colleagues and students, the time is right for educational preparation programs to take a closer look at building new, innovative methods for increasing efficacy through collaborative efforts. This study focuses on 26 school and district leaders from throughout Georgia enrolled in an educational leadership preparation program and their use of immersive simulations as an innovative method to increase self-efficacy in leading professional learning communities.

\section{Literature Review and Conceptual Model}

Professional Learning Communities. There is no universal definition of professional communities (Lomos, Hofman, \& Bosker, 2011); however, most scholars generally assert the meaning centers on teachers examining their practice to improve student learning (Stoll, Bolam, McMahon, Wallace, \& Thomas, 2006). De Neve, Devos, and Tuytens (2015) define professional learning communities as: "a school organization in which a group of teachers share and question their practice from a critical point of view. This questioning happens in an ongoing, reflective, collaborative, and inclusive way..." (p. 32). We use this definition, and primarily use the term professional learning community for reading ease to refer to grade level or interdisciplinary teams.

Professional learning communities have been incorporated into many classroom reform efforts (Duke, 2006; Hord \& Rutherford, 1998) because a growing body of research suggests they facilitate teachers in developing new skills and strengthening their pedagogy 
(Louis \& Marks, 1998; McLaughlin \& Talbert, 1993), which in turn influences and enhances students' learning (Pancucci, 2008; Wiley, 2001). Several studies (Berry, Johnson, \& Montgomery, 2005; Bolam et al., 2005; Hollins, McIntyre, DeBose, Hollins, \& Towner, 2004) have explored the relationship between teachers' participation in professional learning communities and student achievement and found that student learning improved. Phillips (2003) reported that student achievement scores increased dramatically over a three-year period in a middle school's ratings on a state-wide standardized test where scores increased from $50 \%$ of the students passing reading, writing, math, science, and social studies to over $90 \%$ of students passing each subject area test (p. 256). Vescio, Ross, and Adams (2008) reviewed 11 studies that focused on the impact of professional learning communities and concluded that well-developed professional learning communities have positive impact on both teaching practices and student achievement. A meta-analysis of professional learning community research found professional learning communities had a medium effect on student achievement (Lomos et al., 2011). Hughes and Kritsonis's (2007) study of 64 schools in Texas also showed that over a three-year period, $90.6 \%$ of the professional learning community schools achieved higher standardized math test scores with $42.3 \%$ increasing by more than five percentile points.

Self-Efficacy. Self-efficacy refers to a person's belief about his or her capabilities to control his or her own level of functioning in response to events (Bandura, 1997). According to Bandura, the level of self-efficacy determines how much effort will be used, whether coping behavior will be initiated, and the length of sustainability in the face of obstacles and other adverse experiences. "Self-efficacy has to do with self-perception of competence rather than actual level of competence" (Tschannen-Moran, Hoy, \& Hoy, 1998, p. 211). Teacher's efficacy belief refers to one's judgments of his or her ability to ensure desired outcomes of student engagement, especially unmotivated or difficult students (Armor et al., 1976; Bandura, 1997; Tschannen-Moran \& Hoy, 2001). Bandura (1997) later identified teacher efficacy as a type of self-efficacy. Newmann, Rutter, \& Smith (1989) found that high efficacy reduces teacher isolation. Woolfolk and Hoy (1990) reported that teachers' sense of efficacy affects their instructional practice and overall attitude toward the educational process.

Arguably, Bandura (1997) presents one of the more compelling cases linking increased self-efficacy to improved professional practice, stating that stronger perceived efficacy results in more active efforts. Bandura (1997) postulates four sources of efficacyshaping information: (a) mastery experiences, (b) vicarious experiences, (c) affective state, and (d) social persuasion. Mastery experiences are the most influential source of efficacy because personal experiences provide evidence of whether the person has what is needed to succeed (Bandura, 1997). Mastery experiences refer to how the individual performed specific tasks in the past and the outcomes of each task. Vicarious experiences are those in which someone else models the skill in question. Bandura's (1997) third source of efficacy-shaping information, affective state, can be seen as the level of arousal, either anxiety or excitement, that either adds or depletes one's efficacy. Last, social persuasion, is someone's ability to convince another to influence student outcomes and entails feedback from colleagues, community, administration, conferences, book studies, and other gatherings where educational ideas are discussed regarding teachers influencing students toward higher levels of achievement (Goddard, 2003; Skrla, 2002). The research also suggests these four sources of efficacy-shaping information also operate at the collective level (Goddard \& Goddard, 2001). 
Professional Learning Community and Efficacy. While studies have begun only recently to explore the link between professional learning communities and teacher efficacy (Gray \& Summers, 2015; Lee et al., 2011; Voelkel \& Chrispeels, 2017), a few earlier studies have shown that characteristics of professional learning communities have been associated with increased teacher efficacy, especially in collaboration (Lee, Dedrick, \& Smith, 1991; Newmann, et al., 1989). Rosenholtz (1989), for example, conducted a mixed-methods study that involved 78 elementary schools and 1,213 teachers in Tennessee. She looked at five specific measures: shared goals, collaboration, learning opportunities, instructional certainty, and commitment. She found that when teachers worked together in a collaborative culture and celebrated their successes, teachers' sense of self-efficacy contributed significantly to gains in student learning in reading and math over a two-year period. Rosenholtz concluded "teachers' efficacy ... is one of the most powerful predictors of collaboration" (p. 46).

Immersive Simulations as a Pedagogical Tool. The use of immersive simulation to prepare future educators is not a new idea. In 1999, Katz and Bauch reviewed the literature to determine if and how universities were affording opportunities for pre-service teachers to interact in meaningful ways with parents. Simulations surfaced as one tool to provide these real-world interactions, although they were also found to be limited in their use (Katz \& Bauch, 1999). A decade later scholars still called for increases in pedagogy and tools that would expose pre-service teachers to authentic learning opportunities (Dotger, Harris, Maher, \& Hansel, 2011; Johnson, Smith, Willis, Levine, \& Haywood, 2011). Heightened interest in immersive simulation methods and an increase of affordable supporting technology have moved immersive simulation to the forefront at many universities, providing students what Dede (2009) described as "a broader range of...substantial knowledge and skills...through immersive simulation than through conventional instructions or equivalent learning experiences..." (p. 67). Similarly, other researchers have found evidence that immersive simulations provide authentic learning opportunities and support pedagogy, allowing skill development in a risk-free environment (Johnson et al., 2011; Johnson et al., 2016). Most research in this field, however, has focused only on education of pre-service teachers (Straub, Dieker, Hynes, \& Hughes, 2014), suggesting a need for graduate leadership education programs to consider use of immersive simulation as an instructional strategy in educational leadership development programs. As in other fields of leadership education (e.g. medicine, aviation, military, etc.), the use of immersive simulation serves as a signature pedagogy in preparing future leaders (Hughes, Stapleton, Hughes, \& Smith, 2005).

A growing body of research also posits there are learning benefits for students watching others engaged in immersive simulations through vicarious observational learning (VOL) (Hoover, Giambatista, \& Belkin, 2012). In examining the effects of combined participation in immersive simulation with opportunities to observe classmates' interactions in the scenario, Hoover et al. (2012) found that VOL also enhances the direct experience. As suggested by Jenkins (2012), those in leadership education would do well to examine effective teaching and learning of leadership to identify instructional strategies that lead to signature pedagogies. As such, leadership educators who combine immersive simulation experiences with VOL, may discover properly designed immersive simulations scenarios could enhance preparation of educational leaders and become a signature pedagogy in this field.

The purpose of this mixed-methods study was to determine to what degree school and district leaders' perceptions of self-efficacy in leading professional learning communities could be enhanced by participation in a module of immersive simulation. This quasi- 
experimental survey design measured changes in pre- and post-test results and asked an openended question regarding how immersive simulation affected their overall self-efficacy as a leader.

\section{Conceptual Framework}

The conceptual framework was constructed using a three-pronged approach grounded in situated learning (Lave \&Wenger, 1997), critical pedagogy (Freire, 2000) and self-efficacy theory (Bandura, 1977). Situated learning addresses the common disconnects between learning and doing (Lave \& Wenger, 1997). It builds a case for authentic learning opportunities that establish concepts and knowledge as tools applicable to real-world learning (Korthagen, 2010). Relying on tenets of critical pedagogy acknowledges that learning takes place within the context of social power structures (Giroux, 1991) and allows for the purposeful design of immersive simulation through the use of collective wisdom of communities of leaners to challenge the status quo of current educational practices. Selfefficacy, as Bandura (1977) defines it, highlights the relationship between the perception of one's capabilities and its influence on the motivation to act.

As depicted in Figure 1, immersive simulations constructed on tenets of situated learning and critical pedagogy can influence school and district leaders' self-efficacy by bridging the gap between theory and practice and positioning leaders in a community of peers to allow for collective meaning-making that can challenge the status quo. These intersections, within the context of educational leadership preparation, ideally increase school and district leaders' abilities to support effective professional learning communities. This model suggests that their increased self-efficacy in running professional learning communities would ultimately have an impact on: a) the effectiveness of professional learning communities, b) teachers' overall self-efficacy, and c) sustainable school improvement activities. 


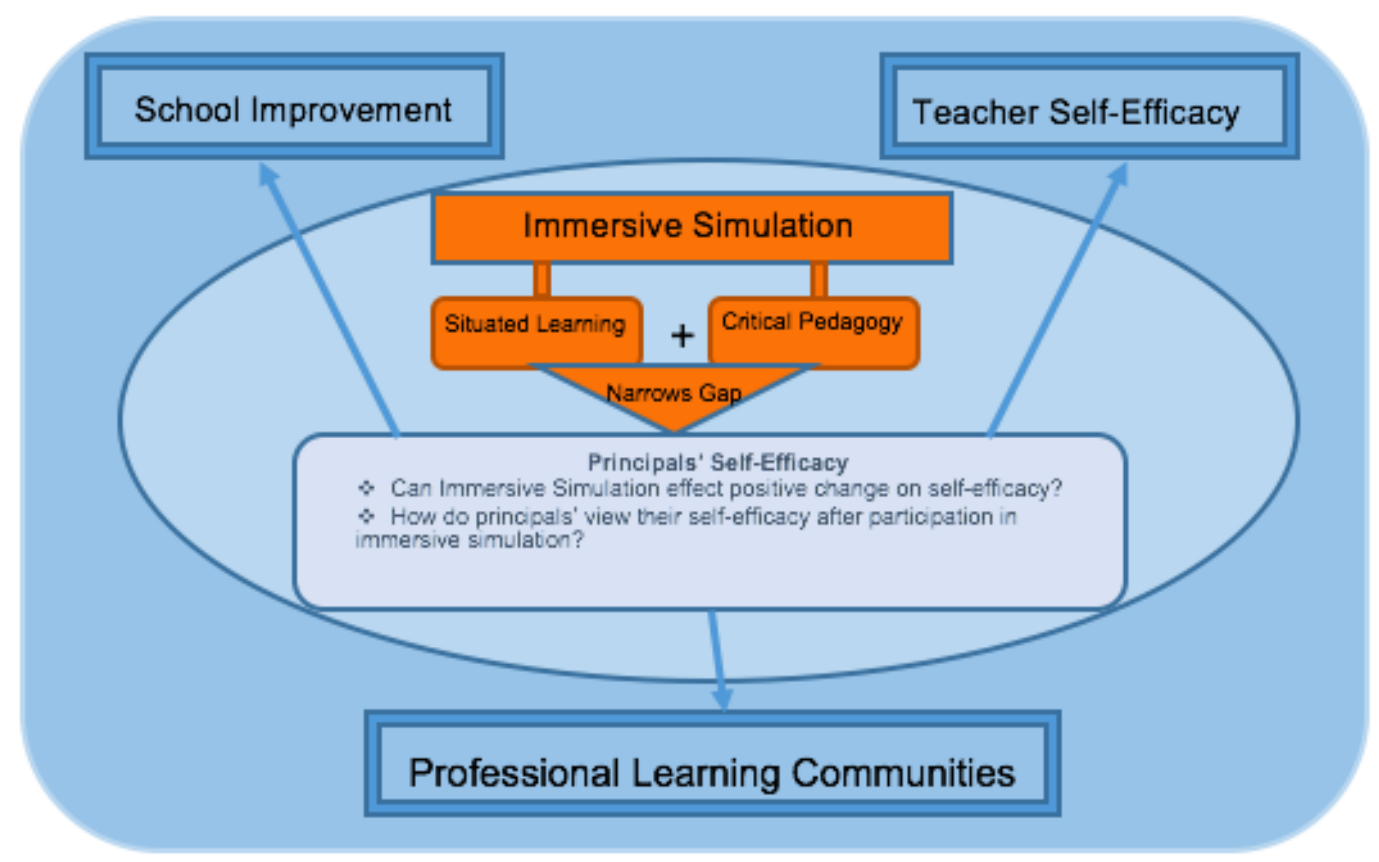

Figure 1

\section{Conceptual Framework}

While research exists connecting school and district leaders' self-efficacy to teachers' practices (e.g., Smith, Guarino, Strom, \& Adams, 2006; Wahlstrom, \& Louis, 2008), more is needed on the relationship between school and district leaders' perceived self-efficacy regarding their ability to run effective professional learning communities and their motivation to support teachers in meaningful execution of them. This study aims to start this conversation by investigating the use of immersive simulations to increase school and district leaders' self-efficacy in successfully leading professional learning communities. In our literature, we highlighted evidence regarding the relationship between professional learning communities, the importance of school and district leaders' ability to direct, implement, and support professional learning communities, and the role of self-efficacy in motivation to change. The literature also highlighted key reasons why professional learning communities do not realize their full potential with school and district leaders' inability to provide appropriate professional development and structures to support teacher growth in this area among the reasons. Therefore, the research questions that guided this study are:

1. To what extent can school and district leaders' perceptions of self-efficacy in leading professional learning communities be enhanced by participation in a module of immersive simulation?

$\mathrm{H}_{1}$ : Perceptions of self-efficacy in facilitating a professional learning community will increase after participation in immersive simulation. $\mathrm{H}_{0}$ : Perceptions of self-efficacy in facilitating a professional learning community will not increase after participation in immersive simulation.

2. How do leaders feel their immersive simulations experiences affected their selfefficacy regarding professional learning communities? 


\section{Methods}

This study explores the effects of immersive simulation on school and district leaders' perceptions of self-efficacy in leading a professional learning community. The results of our study showed the increase in school and district leaders' overall self-efficacy (average mean score of 3.55 to 3.80 on a five-point scale) was statistically significant and was supported by the qualitative data. Our purpose in this article is to present these quantitative and qualitative findings on the usefulness of immersive simulations as a tool for enhancing principal preparation, specifically self-efficacy in leading professional learning communities.

Context of the Study and Data Collection. This study was conducted at a mediumsized university in Georgia. Georgia has undergone significant changes in their educational leadership certification requirements, first in 2007 to require a more job-embedded approach in certification programs, and most recently in 2016 to create a tiered certification system (Georgia Professional Standards Commission, 2016). As such, purposive sampling was used to draw from a pool of school and district level administrators enrolled in educational leadership graduate programs with a strong job-embedded component.

Participants. Participants were recruited from the university through educational leadership courses. Human subject research approval was granted for this research. There were no ethical issues relevant to this research. All students enrolled in the district- or building-level leadership seminar course participated in the treatment $(N=46)$, but only 29 chose to participate in the pre-survey. With 26 completing the post-survey after the treatment, the study had a final sample size of $n=26$. While participation in the immersive simulation module was not anonymous, data gathered were anonymized. To promote anonymity, data were reported in aggregate form only.

Immersive simulation design. Three professional learning community scenarios were designed by the professor and practiced with a simulation specialist who would control an avatar during each immersive simulation scenario at the time of the class. Scenarios were designed such that the avatar's participation would range from pleasant and cooperative to disengaged or uncooperative depending on the scenario randomly chosen by the avatar (simulation specialist). The design was intended to ensure that participants experienced a range of professional learning communities from those that ran smoothly (scenario 1), to those in which one member was not fully invested (scenario 2), to those that were very challenging to manage due to behaviors and potential conflicts between members (scenario 3 ). However, depending on the group's responses to each situation, the avatar could escalate or de-escalate all in the same scenario. In all scenarios, the group was tasked with having a conversation regarding data on student performance on benchmark tests.

As part of a scheduled class, groups of leaders were assigned roles in a professional learning community. Although these groups varied, they usually consisted of three participants interacting simultaneously in the immersive simulation while the rest of the class observed, and provided insights when the group paused the simulation. In each group, one participant was assigned the role of being the facilitator for the professional learning community scenario. Those not in the facilitator role served as participants in the professional learning community, along with the avatar, and also helped with the facilitation process if the leader was having difficulty. The facilitator opened the meeting by saying "start simulation," an indication that the group was ready to start the professional learning community meeting and for the avatar to appear on the screen and join as a member of it. Each professional 
learning community was given ten minutes in the immersive simulation, as according to Dieker, Hynes, Stapleton, \& Hughes (2007), this is believed to be the optimal amount of time for maximum benefit. At times the avatar was completely compliant and agreeable to the process, but when she wasn't, she demonstrated a spectrum of non-compliant behaviors as mild as acting disinterested and being quiet, to as severe as trying to derail the entire professional learning community. Participants could pause the simulation at any point and ask for feedback and direction from their peers. After each simulation, and prior to the next, observers who were not participating were asked to give warm and cool feedback to the participants.

Survey instruments. The instrument used in this study was based on one which was previously developed by the authors to examine changes in self-efficacy of principals after participating in a module of immersive simulation aimed at increasing legal literacy. Questions were modified to reflect the change in participants' perceptions of self-efficacy in a module of immersive simulation on school law to content pertaining to professional learning communities. The dependent variable of self-efficacy is informed by the work of scholars Hoover-Dempsey and Sandler (1997), Hoover-Dempsey et al. (2005), and defined by Bandura's (1997) and Runhaar and her colleagues (2010) definition of occupational selfefficacy. They posit that self-efficacy is positively related to professional development activities in the work setting for educators. Occupational self-efficacy (heretofore referred to as self-efficacy) was measured using a modified version of this previously developed selfefficacy scale to allow for specificity in self-efficacy related to running professional learning communities. While this instrument has not been fully psychometrically evaluated, the previous version of it was found to be reliable with the internal consistency found very high at pre- and posttest, $\alpha=0.89$ and 0.92 respectively (Gilbert, 2017). Cronbach's alpha demonstrates the extent to which responses of a related set of items are similar, with Cronbach's $\alpha \geq .70$ considered a strong indicator of reliability (Moore, Notz, \& Fligner, 2013).

Research Design. Using a quasi-experimental pre-post survey research design, convergent parallel mixed- methods were used to examine to what degree school and district leaders' perceptions of self-efficacy in leading professional learning communities could be enhanced by participation in immersive simulation. Quantitative and qualitative data were collected in parallel, analyzed separately, and then merged. In our study, quantitative data were gathered to test the theory that participation in immersive simulation would positively influence school and district leaders' perceptions of self-efficacy in leading professional learning communities. Qualitative data were gathered to explore if school and district leaders' perceptions of their self-efficacy after participation in immersive simulation supported quantitative findings. Both sets of data were gathered through a survey using Qualtrics. The survey included six Likert-style scale questions and twelve open-ended questions, only one of which was used for this study. Descriptive and correlational data were used to analyze demographics and self-efficacy, respectively. Open, axial, and selective coding was used to develop themes to describe the qualitative data. This research design was chosen to provide a comprehensive analysis (Creswell, 2014) of the use of immersive simulation to improve school and district leaders' self-efficacy in leading a professional learning community.

Data Analysis. Dependent samples $t$ tests were used to test the null hypotheses that perception of self-efficacy in facilitating professional learning communities would not change after participation in a module of immersive simulation. Statistical Package for the Social Sciences (SPSS) was used to calculate dependent samples $t$ tests statistics and $p$ 
values. Changes in matched samples in self-efficacy on the pre-and post-surveys were calculated using the Wilcoxon Signed-Ranks Tests. Effect sizes for both were calculated using Lee Becker's online calculator to ascertain Cohen's $d$ (http://www.uccs.edu/ lbecker/). A questionnaire consisting of nine open-ended item was administered through Qualtrics to gather qualitative data. One question was analyzed for this study. Data from this question were analyzed using Strauss and Corbin's (1990) open, axial, and selective coding scheme to develop categories and themes that allowed us to theorize about the experiences of participants' perceptions in immersive simulation. To promote trustworthiness and credibility, coding was triangulated (Wagner, Kawulich, \& Garner, 2012) by the two of the three researchers independently. Categories were compared and discussed. Once researchers reached agreement on categories, the process was repeated regarding the themes.

Interpretative bias was mitigated in this fashion. The use of myriad quotations from the participants were used to support emerging themes (Cope, 2014). Finally, reliability was promoted by comparing quantitative and qualitative data that were collected in parallel, analyzed separately, and then merged. (Creswell, 2014).

\section{Results}

Demographic data were gathered through a set of survey questions. Frequency statistics were calculated to summarize the demographic data (Table 1). Of the 26 research participants, 38.5\% identified as women; $84.6 \%$ reported they were school leaders, and $92.3 \%$ reported experience leading a professional learning community. Nearly $85 \%$ of research participants reported that been in a school or district leadership role for three years or less.

Table 1

Demographic characteristics of participants $(n=26)$

\begin{tabular}{|c|c|c|}
\hline Characteristics & $N$ & $\%$ \\
\hline \multicolumn{3}{|l|}{$\overline{\operatorname{Sex}}$} \\
\hline Female & 10 & $38.5 \%$ \\
\hline Male & 16 & $61.5 \%$ \\
\hline \multicolumn{3}{|l|}{ Roles in Schools } \\
\hline School Leader (principal) & 22 & $84.6 \%$ \\
\hline Other Leadership & 4 & $15.4 \%$ \\
\hline \multicolumn{3}{|l|}{ Years as school or district leader } \\
\hline Three years or less & 22 & $84.6 \%$ \\
\hline Zero to less than one year & 4 & $15.4 \%$ \\
\hline \multicolumn{3}{|c|}{ Experience Leading Professional Learning Communities } \\
\hline Experienced & 24 & $92.3 \%$ \\
\hline No Experience & 2 & $7.7 \%$ \\
\hline
\end{tabular}




\section{To what extent can school and district leaders' perceptions of self-efficacy in leading professional learning communities be enhanced by participation in immersive simulation?}

Quantitative data were collected using five item Likert-style response scale. The internal consistency for the data collected using this instrument was found to be high at preand posttest, $\alpha=0.76$ and 0.86 respectively. A dependent samples $t$ test was calculated and an increase in self-efficacy was observed $(t(25)=3.043, p>.05, d=0.39)$ as the mean increased from $M=3.55(S D=.60)$ to $M=3.80(S D=.67)$. This change is qualified by a moderate effect size, $d=.39$. This is evidence that school and district leaders' self-efficacy in leading a professional learning community increased after participation in immersive simulation.

Table 2

Pre/post changes in self-efficacy

\begin{tabular}{|c|c|c|c|c|c|c|}
\hline \multirow[b]{2}{*}{ Overall Changes } & \multicolumn{2}{|l|}{ Pre } & \multicolumn{2}{|l|}{ Post } & \multirow[b]{2}{*}{$t$} & \multirow[b]{2}{*}{$d$} \\
\hline & $\bar{M}$ & $S D$ & $\bar{M}$ & $S D$ & & \\
\hline Self-Efficacy & 3.55 & 0.60 & 3.80 & 0.67 & 3.043 & 0.39 \\
\hline
\end{tabular}

To further examine the observed differences and aid in the interpretation of changes in overall self-efficacy, analyses of each survey item were conducted using a Wilcoxon Signed- Ranks Test. Results indicated significant differences in questions 1 and 4 (see Table $3), Z=2.972, p<.05, d=.54$ and $Z=1.219, p<.05, d=.50$, respectively. Results did not indicate significant differences in questions, two, three, and five (see Table 3), $Z=1.081, p>$ $.05, d=.19 ; Z=0.513, p>.05, d=.10$; and $Z=1.291, p<.05, d=.22$. Changes in questions two, three, and five did not approach statistical significance. It is important to note that small effect sizes were associated with changes in each suggesting that this test may be underpowered to detect a statistically significant change. These data suggest that while perceptions of self-efficacy increased in some aspects, in others it did not. For example, participants felt that their preparation gave them a solid knowledge base in leading professional learning communities, and that they were more confident in their ability to handle difficult situations that might arise in professional learning community meetings.

Qualitative data were collected in the convergent design and used to compare school and district leaders' perceptions of their experience to their ratings of self-efficacy. Open, axial, and selective coding were used to analyze these data. From the responses provided, twenty-three codes were collapsed into five categories. These five categories were analyzed for commonalities with two themes emerging from data analysis. As discussed below, these themes reinforce the overall findings of the quantitative analysis. 
Table 3

Wilcoxon Signed-Ranks Test for self-efficacy survey questions

\begin{tabular}{|c|c|c|c|c|c|c|c|}
\hline \multirow[b]{2}{*}{ Overall Changes } & \multicolumn{2}{|r|}{ Pre } & \multicolumn{2}{|c|}{ Post } & \multirow[b]{2}{*}{$Z$} & \multirow[b]{2}{*}{$p$} & \multirow[b]{2}{*}{$d$} \\
\hline & $M$ & $S D$ & $M$ & $S D$ & & & \\
\hline $\begin{array}{l}\text { Q.1 I feel my leadership } \\
\text { preparation provided me with } \\
\text { a strong knowledge base for } \\
\text { leading Professional Learning } \\
\text { Communities (PLC). }\end{array}$ & 3.38 & 0.94 & 3.85 & 0.78 & 2.972 & 0.03 & 0.54 \\
\hline $\begin{array}{l}\text { Q.2 I feel very confident in } \\
\text { my overall knowledge } \\
\text { regarding leading PLCs. }\end{array}$ & 3.65 & 0.89 & 3.81 & 0.85 & 1.080 & 0.28 & 0.19 \\
\hline $\begin{array}{l}\text { Q.3 I feel very confident in } \\
\text { my ability to lead a PLC. }\end{array}$ & 3.77 & 0.77 & 3.85 & 0.83 & 0.513 & 0.60 & 0.10 \\
\hline $\begin{array}{l}\text { Q.4 I feel very confident in } \\
\text { my ability to handle difficult } \\
\text { group dynamics in a PLC. }\end{array}$ & 3.35 & 0.80 & 3.73 & 0.72 & 2.486 & 0.01 & 0.50 \\
\hline $\begin{array}{l}\text { Q.5 I feel my preparation has } \\
\text { enhances my ability to leader } \\
\text { a PLC. }\end{array}$ & 3.77 & 0.16 & 0.77 & 0.14 & 1.291 & 0.20 & 0.22 \\
\hline
\end{tabular}

\section{How do leaders feel their immersive simulations experiences affected their self-efficacy regarding professional learning communities?}

The first theme that emerged from analysis of the data was that participation in immersive simulation improved overall confidence in district and building leaders' ability to lead professional learning communities. After involvement in immersive simulation, which replicated an authentic professional learning community meeting, participants indicated myriad ways in which simulations "improved" their confidence. For example, participants 2, 3 , and 4, respectively stated they had increased confidence in "... approach[ing] meetings without fear," in "handl[ing] difficult situations and "assess[ing] group dynamics." Because the avatar's behavior in the immersive simulation varied by scenario, the type of confidence participants expressed varied as well. While participant 13 spoke of being "more prepared and knowledgeable" about professional learning communities, participant 11 focused on being able to "juggle different conflicts and think through them quickly." Some comments highlighted the value of watching their peers and reflecting as a group in increasing their overall confidence. For example, participant 5 stated that it showed how "others handle situations similar to the way I would," while participants 23 and 25 highlighted that it allowed for them to think about how to "respond" in lieu of having to "react." Participant 17 shared that it allowed "practice we might not get in the new world," a sentiment expressed by several. These types of comments reinforce that building confidence was a common effect of exposure to immersive simulation.

The second theme that emerged from analysis of the data was a sense of refined or expanded skills in the context of new approaches to leading professional learning communities. School and district leaders were able hone existing skills through exposure to 
immersive simulation by both participating in, and observing a variety of professional learning community scenarios in which they tried and collectively assessed several approaches. Sixty-five percent of participants reported that their participation and observation had shown them either a new approach, allowed them to hone existing skills, or both. For example, participant 10, "it has provided me a different approach to beginning professional learning community meetings" and participant 12 reported, "It made me realize I have to set an agenda and protocol...to stay focused." Other participants spoke of learning new approaches to building effective relationships that support organizations of learning before transitioning to topic of examining the data. For example, participant 16 stated it "brings out the ability to relate" and similarly, participant 19 reported that helped in "building positive relationships with member[s] of a PLC." These types of realizations go beyond promoting confidence to the building of skills. Of those who felt they already had skills in leading professional learning communities, their comments reflected the benefits of practice.

Participant 7 stated, "This strengthened my toolbox" and several indicated (participants 1, 22, 24 , and 26) that the opportunity encouraged "reflective practice,"-something lacking in many educational settings. Participant 24 summed up the sentiment this way:

I believe these experiences have caused me to reflect not only on the simulations, but to past 'live' experiences to determine what I do well, and where I need to grow. This allows me to be intentionally [sic] in seeking out situations that will allow me to improve my practice.

These opportunities to engage in reflective practices support increased self-efficacy by affording participants consideration of new approaches and the honing of existing skills.

\section{Discussion and Conclusions}

The purpose of our study was to explore to what extent school and district leaders' perceptions of self-efficacy in leading professional learning communities could be enhanced by participation in immersive simulation. Our findings show (a) there is an increase in overall self-efficacy ratings in leading professional learning communities after exposure to, and participation in, immersive simulations; and (b) higher levels in perceived confidence, the acquisition of new skills, and opportunities to hone existing skills. Thus, this study confirms many others on immersive simulation that examine an increase in self-efficacy as a primary measure of participation (e.g., Badiee \& Kaufman, 2015; Bautista 2013; Peterson, 2014). Previous studies also have examined increases in self-efficacy for educational leaders specifically in school law (Gilbert, 2017); however, to date, none have examined increases in self-efficacy of leading professional learning communities through immersive simulations.

Despite an increase in overall self-efficacy, changes in two questions (numbers 1 and 4, see Table 3), were statically significant on the Wilcoxon Signed-Rank Tests. With the remaining three individual questions (numbers 2, 3, and 5, see Table 3), although changes did not approach statistical significance, each change was supported by small effect sizes. Further research, with a more robust sample size is suggested to explain the lack of statistically significant change in these questions. Changes of statistical significance in questions 1 and 4 merits discussion, particularly given each was supported by moderate effect size. These questions examined overall knowledge base and confidence in handling group dynamics (questions 1 and 4, respectively). 
It is clear from the results of question 1 that although district and school leaders felt that their programs had prepared them well $(M=3.38)$, immersive simulations added to their overall knowledge base $(M=3.85)$. This suggests a usefulness of immersive simulation to meet the needs of a range of district and school leaders' experiences. Results from question 4 indicated that participants felt increased confidence in handling a difficult professional learning community group $(M=3.35, M=3.73)$. This suggests that participants benefited from the range of behaviors displayed by the avatar in the scenarios regardless of their role in each immersive simulation experience. The design of the immersive simulation scenario built on the assertion by Hoover and her colleagues (2012) that when direct participation is combined with vicarious learning opportunities, learning is enhanced. Allowing for repeated opportunities to learn both vicariously and directly left participants clearly more confident that they could successfully lead professional learning communities in which participants displayed challenging behaviors. These experiences improved application of existing knowledge and prompted the generation of new knowledge.

Results of the qualitative data highlighted the use of two sources of efficacy-shaping opportunities in immersive simulations, mastery experiences and vicarious learning. While participants did not report mastery of skill specifically, they did report that opportunities to tweak nuances of their approach immediately after having paused a simulation helped them hone existing skills. Deep and rich learning occurred as these opportunities allowed for examination, questioning, and analysis of efficacy of approaches, followed by re-application of a more sophisticated understanding of how to manage the dynamics of a professional learning community. Because the scenarios were designed to create a community of learners, participants were empowered to draw from their collective experiences when pausing and isolating events of the immersive simulation. This time and opportunity to learn vicariously with, and through, others' experiences prompted critical conversations that often deconstructed the status quo, encouraged collaborative construction a more effective approaches, and increased participants' willingness to try these new approaches. In a risk-free environment, assumptions were challenged, new knowledge was created, and these leaders improved their self-efficacy to address real-world challenges of professional learning communities. As such, our study suggests those in graduate leadership education might look to the combination of immersive simulation experiences with VOL as effective teaching and learning pedagogy.

Observation of, and participation in, immersive simulation focused on leading professional learning communities improves district and school leaders' self-efficacy in this area. Many studies highlight professional learning communities as central to school improvement efforts because, when run properly, they allow teachers to improve their pedagogy (Louis \& Marks, 1998; McLaughlin \& Talbert, 1993). This improved pedagogy has a positive and moderate impact on students' learning (Lomos et al., 2011; Pancucci, 2008; Wiley, 2001). However, for this to hold true, schools must implement professional learning communities well, a task with which many schools struggle (Huberman, 1993; Little, 1995; Voelkel \& Chrispeels, 2017). In today's current accountability era in the United States, great responsibility for school improvement is placed on school leaders (Voelkel, Johnson, \& Gilbert, 2016). Part of that responsibility includes creating and providing professional development and structures that grow teachers' capacity to participate effectively in, and run, professional learning communities. 


\section{Implications for Practice}

Those involved in leadership education, who focus specifically on the preparation of educational leaders and their responsibility to orchestrate and direct school improvement, may want to consider the use of immersive simulations as a pedagogical tool. Specifically, this pedagogy shows promise when used as a tool in preparing educational leaders in school law (Gilbert, 2017) and as a means to increase leaders' self-efficacy in leading professional learning communities. Given that both teacher and collective efficacy have an impact on a school's ability to improve, along with Stoll and his colleagues' (2006) assertion that professional learning communities are a promising means to building improvement capacity, arming school and district leaders with the belief that they can lead and support professional learning communities could be an important focal point in their preparation and in school improvement efforts. Increased skill development and self-efficacy in this area can be accomplished through comprehensive exposure to immersive simulations constructed on the tenets of situated learning and critical pedagogy, resulting in increased motivation for leaders to provide meaningful professional development that supports professional learning communities in the workplace.

This study also has implications for educational leadership training that takes place outside of universities. For example, on-going professional development of current school leaders is reported to be effective when relying on immersive simulation pedagogy, as over $80 \%$ of the participants reported that they are in the role of a principal. Immersive simulation scenarios can be designed and delivered to school leaders even after their formal schooling has been completed. These professional development opportunities could provide sustained growth of school and district leaders' skillsets in supporting the vital work of professional learning communities and ensuring that they reach their full potential. Use of immersive simulation in this manner could substantially narrow the gaps between theory and practice. While more research is warranted in this area, given the sample size and limits of generalizability, these findings suggest a possible avenue for creating a broader collective self-efficacy in schools, rendering them more flexible and adaptable to the changing political and social contexts.

\section{Areas for Future Research}

This study lays the groundwork for future research in two areas. Those wishing to examine instructional strategies in educational leadership might focus on the emergence of immersive simulation and VOL in their programs. While not yet a pervasive instructional strategy in educational leadership development, its wide use as a means of teaching and learning in other areas of leadership education (e.g., the military, medicine, aviation, etc.) might signal its emergence as a signature pedagogy in leadership development. Others may more specifically aim to examine the relationship between school and district leaders' selfefficacy in leading professional learning communities and schools' ability to effectively implement and sustain them. Given that research suggests professional learning communities are not used to their full potential in schools (Huberman, 1993; Little, 1995; Voelkel \& Chrispeels, 2017), it is imperative that the field investigate new strategies to increase professional learning communities' effectiveness in creating, supporting, and sustaining schools' transformation to learning organizations. Because effective professional learning communities have a positive and corollary effect on teacher self-efficacy (Lee et al., 2011), and because collective efficacy may influence student achievement (Goddard et al., 2004), further exploration of training through this modality is a worthwhile endeavor. 


\section{References}

Armor, D., Conry-Osequera, P., Cox, M., King, N., McDonnell, L., \& Pascal, A. (1976). Analysis of the school preferred reading program in selected Los Angeles minority schools. Santa Monica, CA: RAND (Eric Document Reproduction Service No. ED 130243).

Ashton, P. T., \& Webb, R. B. (1986). Making a difference: Teachers' sense of efficacy and student achievement. New York, NY: Longman Publishing Group.

Badiee, F. \& Kaufman, D. (2015). Design evaluation of a simulation for teacher education. Sage Open, 5(2), 1-10. doi:10.1177/2158244015592454

Bandura, A. (1997). Self-Efficacy: The exercise of control. New York: W. H. Freeman and Company.

Berry, B., Johnson, D., \& Montgomery, D. (2005). The power of teacher leadership. Educational Leadership, 62(5), 56. Retrieved from http://www.ascd.org/

Bolam, R., McMahon, A., Stoll, L., Thomas, S., \& Wallace, M. (with Greenwood, A., Hawkey, K., Ingram, M., Atkinson, A., \& Smith, M.). (2005). Creating and sustaining professional learning communities (Research Report No. 637). London, UK: General Teaching Council for England, Department for Education and Skills.

Bradley, E. G., \& Kendall, B. (2015). A review of computer simulations in teacher education. Educational Technology Systems, 43(1), 3-12. doi:http://dx.doi.org/10.2190/ET.43.1.b

Cope, D. G. (2014). Methods and meanings: Credibility and trustworthiness of qualitative research. Oncology Nursing Forum, 41(1), 89-91. doi:10.1188/14.ONF.89-91

Creswell, J. W. (2014). Research design: Qualitative, quantitative and mixed methods approaches. Los Angeles, CA: Sage Publishing.

Dede, C. (2009). Immersive interfaces for engagement and learning [Online Magazine]. Science Mag, 323, 66-69. Retrieved from http://www.sciencemag.org/content/323/5910/66.full

De Neve, D., Devos, G., \& Tuytens, M. (2015). The importance of job resources and selfefficacy for beginning teachers' professional learning in differentiated instruction. Teaching and Teacher Education, 47, 30-41. Retrieved from https://www.journals.elsevier.com

Dieker, L., Hynes, M., Stapleton, C., \& Hughes, C. (2007). Virtual Classrooms: STAR simulator building virtual environments for teacher training in effective classroom management. New Learning Technology SALT, 4, 1-22. Retrieved from http://www.salt.org/salt.asp?ss=1\&pn=jobListAll 
Dotger, B. H., Harris, S., Maher, M., \& Hansel, A. (2011). Exploring the emotional geographies of parent-teacher candidate interactions: An emerging signature pedagogy. The Teacher Educator, 46(3), 208-230.

doi:10.1080/08878730.2011.581882

Duke, D. L. (2006) What We Know and Don't Know about Improving Low-Performing Schools. Phi Delta Kappan, 87(10), 729-734. Retrieved from http://journals.sagepub.com/

Elmore, R. F. (2004). School reform from the inside out: Policy, practice, and performance. Cambridge, MA: Harvard Education Press.

Freire, P. (2000). Pedagogy of the oppressed. London, GB: Bloomsbury Publishing.

Georgia Professional Standards Commission (2016). Rule changes and tiered system [Informational Letter]. Retrieved from https://www.gapsc.com

Gilbert, K. A. (2017). Investigating the use and design of immersive simulation to improve self-efficacy and for aspiring principals. Journal of Information Technology Education: Innovations in Practice, 16, 127-169. Retrieved from http://www.informingscience.org/Publications/3726

Giroux, H. (1991). Border crossings: Cultural workers and the politics of education. New York, NY: Routledge.

Goddard, R. D. (2003). The impact of schools on teacher beliefs, influence and student achievement: The role of collective efficacy beliefs. In J. Rath \& A.C. McAninch (Eds.), Teacher beliefs and classroom performance: The impact of teacher education (pp. 183-204). Greenwich, CT: Information Age.

Goddard, R. D. \& Goddard, Y. L. (2001). A multilevel analysis of the relationship between teacher and collective efficacy in urban schools. Teaching and Teacher Education, 17, 807-818. Retrieved from https://www.journals.elsevier.com

Goddard, R. D., Hoy, W. K., \& Woolfolk-Hoy A. (2000). Collective teacher efficacy: Its meaning, measure, and impact on student achievement. American Educational Research Journal, 37(2), 479-507. Retrieved from http://journals.sagepub.com/

Goddard, R. D., Hoy, W. K., \& Woolfolk-Hoy A. (2004). Collective efficacy beliefs: Theoretical developments, empirical evidence, and future directions. Educational Researcher, 33(3), 3-13. Retrieved from http://journals.sagepub.com/

Gray, J. A., \& Summers, R. (2015). International professional learning communities: The role of enabling school structures, trust, and collective efficacy. International Education Journal: Comparative Perspectives, 14(3), 61-75. Retrieved from http://www.iejcomparative.org/ 
Halverson, R. (2007). How leaders use artifacts to structure professional community in schools. In L. Stoll \& K S. Louis, (Eds.) Professional Learning Communities: Divergence, Depth and Dilemmas, pp. 93-105. New York, NY: McGraw-Hill Open University Press.

Hattie, J. (2009). Visible learning: A synthesis of over 800 meta-analyses relating to achievement. New York: Routledge.

Hollins, E. R., McIntyre, L. R., DeBose, C., Hollins, K. S., \& Towner, A. (2004). Promoting a self-sustaining learning community: Investigating an internal model for teacher development. International Journal of Qualitative Studies in Education, 17(2), 247264. Retrieved from http://www.tandfonline.com/

Hoover, J. D., Giambatista, R. C., \& Belkin, L. Y. (2012). Eyes on, hands on: Vicarious observational learning as an enhancement of direct experience. Academy of Management Learning \& Education, 11(4), 591-608. doi:10.5465/amle.2010.0102

Hoover-Dempsey, K. V., \& Sandler, H. M. (1997). Why do parents become involved in their children's education? Review of Educational Research, 67(1), 3-42. doi:10.3102/00346543067001003

Hoover-Dempsey, K.V., Walker, J. M. T., Sandler, H. M., Whetsel, D., Green, C. L., Wilkins, A. S., \& Closson, K. (2005). Why do parents become involved? Research findings and implications. The Elementary School Journal, 106(2), 105-130. doi:10.1086/499194

Hord, S. M., \& Rutherford, W. L. (1998). Creating a professional learning community: Cottonwood creek school. Issues...About Change, 6(2). Retrieved from www.sedl.org/change/issues/issues62/issues62.pdf

Huberman, M. (1993). The model of the independent artisan in teachers' professional relations, In J.W. Little \& M.W. McLaughlin (Eds). Teachers' Work. New York, NY: Teachers College

Hughes, T. A., \& Kritsonis, W. A. (2007). Professional learning communities and the positive effects on student achievement: A national agenda for school improvement. The Lamar University Electronic Journal of Student Research, Spring, 2007. Retrieved from http://www.allthingsplc.info/files/uploads/plcandthepositiveeffects.pdf

Hughes, C. E., Stapleton, C. B., Hughes, D. E., \&amp; Smith, E. M. (2005). Mixed reality in education, entertainment, and training. Computer Graphics and Applications, IEEE, 25(6), 24-30. doi:10.1109/MCG.2005.139

Jenkins, D. M. (2012). Exploring Signature Pedagogies in Undergraduate Leadership Education. Journal of Leadership Education, 11(1). Retrieved from http://www.journalofleadershiped.org/ 
Johnson, L., Adams Becker, S., Cummins, M., Estrada, V., Freeman, A., \& Hall, C. (2016). NMC Horizon Report: Higher Education Edition. Austin, Texas: The New Media Consortium.

Johnson, L., Smith, R., Willis, H., Levine, A., \& Haywood, K., (2011). The 2011 Horizon Report. Austin, TX: The New Media Consortium. Retrieved from http://www.nmc.org/pdf/2011-Horizon-Report.pdf

Katz, L., \& Bauch, J. P. (1999). The Peabody Family Involvement Initiative: Preparing preservice teachers for family/school collaboration. The School Community Journal, 9(1), 49-68. Retrieved from http://www.schoolcommunitynetwork.org/scj.aspx

Korthagen, F. A. J. (2010). Situated learning theory and the pedagogy of teacher education: Towards an integrative view of teacher behavior and teacher learning. Teaching and Teacher Education, 26, 98-106. doi:10.1016/j.tate.2009.05.001

LaRocco, D. (2007). On the path to becoming a professional learning community: Charting change in one suburban middle school. Journal of Research for Educational Leaders, 4(1), 75-101. Retrieved from http://www2.education.uiowa.edu/

Lave, J. \& Wenger, E. (1991). Situated learning: Legitimate peripheral participation. Cambridge, MA: Cambridge University Press.

Lee, J. C., Zhang, Z., \& Yin, H. (2011). A multilevel analysis of the impact of a professional learning community, faculty trust in colleagues and collective efficacy on teacher commitment to students. Teaching and Teacher Education, 27, 820-830. Retrieved from https://www.journals.elsevier.com

Lee, V. E., Dedrick, R. F., \& Smith, J. B. (1991). The effect of the social organization of schools on teachers' efficacy and satisfaction. Sociology of Education, 64, 190-208. Retrieved from https://us.sagepub.com

Leithwood, K., Louis, K. S., Anderson, S., \& Wahlstrom, K. (2004). Review of research how leadership influences student learning. Retrieved from http://www.wallacefoundation.org/Pages/a-review

Little, J. W. (1995) Contested ground: The basis of teacher leadership in two restructuring high schools. Elementary School Journal, 96(1), 47-63. Retrieved from http://www.journals.uchicago.edu/

Lomos, C., Hofman, R. H., \& Bosker, R. J. (2011). Professional communities and student achievement - a meta-analysis. School Effectiveness and School Improvement, 22(2), 121-148. Retrieved from http://www.tandfonline.com/

Louis, K. S., \& Marks, H. M. (1998). Does professional community affect the classroom: Teachers' work and student experiences in restructuring schools. American Journal of Education, 106(4), 532-575. Retrieved from http://www.journals.uchicago.edu/ 
McLaughlin, M. W. \& Talbert, J. E. (1993). Contexts that matter for teaching and learning. Stanford: Center for Research on the Context of Secondary School Teaching, Stanford University.

Moore, D. S., Notz, W. I., \& Fligner, M. I. (2013). The basic practice of statistics (6th ed.). New York, NY: W.H. Freeman.

Newmann, F., Rutter, R., \& Smith, M. (1989). Organizational factors that affect school sense of efficacy, community, and expectations. Sociology of Education, 62(4), 221-238. Retrieved from https://us.sagepub.com

Pancucci, S. (2008). A retrospective analysis of a professional learning community: How teachers' capacities shaped it. International Journal of Social Science, 3, 62-69. Retrieved from http://www.iises.net/

Peterson, M. B. (2014). Pre-service special education teacher's frequency of opportunities to respond in the TeachLivE ${ }^{T M}$ virtual classroom. (Doctoral dissertation). Retrieved from Scholarworks dissertations. (AAI3326154)

Phillips, J. (2003). Powerful learning: Creating learning communities in urban school reform. Journal of Curriculum and Supervision, 18(3), 240-258. Retrieved from http://www.ascd.org/

Rosenholtz, S. (1989). Teacher's workplace: The social organization of schools. New York: Longman.

Runhaar, P., Sanders, K., \& Yang, H. (2010). Stimulating teachers' reflection and feedback asking: An interplay of self-efficacy, learning goal orientation, and transformational leadership. Teaching and Teacher Education, 26(5), 1154-1161. Retrieved from https://www.journals.elsevier.com/

Scribner, J. P., Cockrell, K. S., Cockrell, D. H., \& Valentine, J. W. (1999). Creating professional communities in schools through organizational learning: An evaluation of a school improvement process. Educational Administration Quarterly, 35(1), 130160. Retrieved from http://journals.sagepub.com/

Skrla, L. (2002). Productive campus leadership responses to accountability: Principals as policy mediators. In W. Hoy \& C. Miskel (Eds.), Studies in Leading and Organizing Schools (pp. 27-50). Greenwich, CT: Information Age Publishing.

Smith, W., Guarino, A., Strom, P., \& Adams, O. (2006). Effective teaching and learning environments and principal self-efficacy. Journal of Research for Educational Leaders, 3(2), 4-23. Retrieved from http://www2.education.uiowa.edu/

Stoll, L., Bolam, R., McMahon, A., Wallace, M., \& Thomas, S. (2006). Professional learning communities: A review of the literature. Journal of Educational Change, 7(4), 221258. Retrieved from https://link.springer.com/ 
Straub, C., Dieker, L., Hynes, M., \& Hughes, C. (2014, June). Year 1 findings: Using virtual rehearsal in TLE TeachLivE ${ }^{T M}$ mixed reality classroom simulator to determine the effects on the performance of mathematics teachers. Paper presented at the 2014 TeachLivE National Research Project, Orlando, Florida. Retrieved from http://teachlive.org/wp-content/uploads/2014/12/2014-Teachlive-ConferenceProceedings.pdf

Strauss, A., \& Corbin, J. M. (1990). Basics of qualitative research: Grounded theory procedures and techniques. Boston, MA: Sage Publications.

Tschannen-Moran, M., \& Hoy, A. W. (2001). Teacher efficacy: Capturing an elusive construct. Teaching and Teacher Education, 17, 783-805. Retrieved from https://www.journals.elsevier.com

Tschannen-Moran, M., Woolfolk-Hoy, A., \& Hoy, W. K. (1998). Teacher efficacy: Its meaning and measure. Review of Educational Research, 68 (2), 202-248. Retrieved from http://journals.sagepub.com/

U.S. Department of Education. (2015). Every Student Succeeds Act. Retrieved February 4, 2016, from http://www.ed.gov/ESSA.

Vescio, V., Ross, D., \& Adams, A. (2008). A review of research on the impact of professional learning communities on teaching practice and student learning. Teaching and Teacher Education, 24, 80-91. Retrieved from https://www.journals.elsevier.com

Voelkel Jr, R. H., \& Chrispeels, J. H. (2017). Understanding the link between professional learning communities and teacher collective efficacy. School Effectiveness and School Improvement, 1-22.

Voelkel, R. H., Johnson, C. W., \& Gilbert, K. A. (2016). Use of Immersive Simulations to Enhance Graduate Student Learning: Implications for Educational Leadership Programs. Online Journal of Distance Learning Administration, 19(2), 1-16. Retrieved from http://www.westga.edu/ distance/ojdla/browsearticles.php

Wahlstrom, K. L., \& Louis, K. S. (2008). How teachers experience principal leadership: The roles of professional community, trust, efficacy, and shared responsibility. Educational Administration Quarterly, 44(4), 458-495. Retrieved from http://journals.sagepub.com/

Wiley, S. D. (2001). Contextual effects on student achievement: School leadership and professional community. Journal of Educational Change, 2, 1-33. Retrieved from https://link.springer.com

Wagner, C., Kawulich, B., \& Garner, M. (2012). Doing social research: A global context. New York, NY: McGraw-Hill Higher Education.

Woolfolk, A. E., \& Hoy, W. K. (1990). Prospective teachers' sense of efficacy and beliefs about control. Journal of Educational Psychology, 82(1), 81-91. Retrieved from http://www.apa.org/ 


\section{Author Biographies}

Kristen A. Gilbert serves as an assistant professor at Augusta University and as a school improvement consultant. Her research focuses on leadership for educational equity, which includes leadership preparation, leadership practices in school, and school law and policies. Dr. Gilbert is 24-year public school veteran teacher and administrator. Contact information:

Department of Teaching and Leading

Augusta University

$112015^{\text {th }}$ Street

Augusta, GA 30904

krgilbert@augusta.edu

Office: 706-729- 2495

Fax: 706-729- 2276

Cell: 207-877- 4261

Robert H. Voelkel, Jr. is an assistant professor, Department of Teacher Education and Administration, University of North Texas. His research interests include school reform, professional learning communities and teacher collective efficacy, leadership, and social justice. He is also interested in immersive simulations and their role in effective PLC teams and leadership development. Contact information:

Department of Teacher Education and Administration

University of North Texas

1155 Union Circle

Denton, TX 76203-5017

robert.voelkel@unt.edu; rh_voelkel@yahoo.com

Office: $940-565-4800$

Fax: $940-565-4952$

Cell: $858-442-1625$

Christie W. Johnson is assistant professor, Department of Leadership, Research, and School Improvement, University of West Georgia. Her research interests include talent management, strategic planning, and PLCs. She is also interested in the role of immersive simulations on leadership development. Johnson is a 30-year public school veteran teacher, principal, and assistant superintendent. Contact information:

Department of Leadership, Research, and School Improvement

University of West Georgia 1601 Maple Street

Carrollton, GA 30118-5160

cjohnson@westga.edu

Office: 678-839- 6167

Fax: 678-839- 6195

Cell: 770-378- 0495 